\title{
Anal condylomas in men. 1. Histopathological and virological assessment
}

\author{
STINA M SYRJÄNEN,* GEO vON KROGH,† KARI J SYRJÄNEN*‡
}

From the *Department of Pathology, University of Kuopio, Finland; the †Department of Dermatology, Karolinska Hospital, and Venhälsan at Södersjukhuset, Stockholm, Sweden; and the $\ddagger$ Laboratory of Pathology and Cancer Research, Finnish Cancer Society, Kuopio, Finland

SUMMARY A series of 128 biopsy specimens from anal condylomas in 73 homosexual or bisexual and 38 heterosexual men (mean (SD) age $31.8(9.6)$ years) were subjected to histological assessment and human papillomavirus (HPV) typing by in situ DNA hybridisation with ${ }^{35}$ S-labelled HPV 6, 11, 16, 18,31 , and 33 probes. Most patients were also tested serologically for antibodies to human immunodeficiency virus (HIV). As evaluated on light microscopy, most (74\%, 95/128) of the lesions were exophytic (papillary) acuminate warts, 15\% (19) were flat, and $11 \%$ (14) were pigmented papulous lesions. No signs of anal intraepithelial neoplasia (AIN) were seen in $70 \%$ (90) of the 128 biopsy specimens (NAIN), 27\% (35) were classified as showing AIN I, and another $2 \%$ (three) as AIN II. AIN was significantly $(p<0.05)$ more often associated with papulous lesions, only $43 \%$ (6/14) of which showed NAIN compared with $72 \%$ (68/98) of acuminate condylomas. The duration of disease was directly related to the presence and severity of AIN in the lesions; thus in 47 lesions that had been present for more than 12 months, NAIN was found in $31(66 \%)$, AIN I in $14(30 \%)$, and AIN II in two (4\%).

HPV DNA of at least one of the six types tested for was detected in 109/125(87\%) lesions. HPV 6 and HPV 11 were the two most common types, comprising $57 \%(62)$ and $37 \%(40)$, respectively, of the 109 HPV DNA positive cases. Only seven $(6 \%)$ biopsy specimens were associated with any of HPV types $16,18,31$, or 33 , which carry a high risk of potential malignant transformation. No association was found between sexual preferences of patients and the incidence of any of the various HPV types. Neither did the distribution of the various HPV types differ between men with antibody to HIV and those without antibody. All the men with antibody to HIV were homosexual or bisexual. On microscopy, 93\% (38) of 41 lesions containing HPV 11 and 75\% (48/64) of HPV 6 lesions were of the acuminate wart type; in comparison, the remaining 16 HPV 6 lesions were equally either flat or papulous (eight, 13\% each). Of the 64 HPV 6 and 41 HPV 11 associated lesions, $73 \%$ (47) and $63 \%$ (26), respectively, were classified as NAIN. Only two lesions were associated with HPV 16, and both showed mild dysplasia. On the other hand, two HPV 6 induced lesions were associated with AIN II. No differences were found between HPV 6 and HPV 11 in duration of disease; (39\%, and 37\% respectively, had been present for more than 12 months). The results showed that overt anal wart disease was associated with HPV types 6 and 11 in most cases. Although HPV types considered as being of higher oncogenic potential were detected relatively rarely, the associated AIN in a relatively high proportion $(31 \%, 32 / 105)$ of HPV 6 or 11 induced lesions indicated that a malignant potential, even for HPV 11 associated anal warts, cannot be excluded.

Overt genitoanal warts (condylomata acuminata or condylomas) represent a sexually transmitted disease

Address for reprints: Dr Kari J Syrjänen, Department of Pathology, University of Kuopio, POB 6, SF-70211 Kuopio, Finland

Accepted for publication 21 January 1989
(STD) that afflicts both sexes. ${ }^{12}$ Human papillomavirus (HPV) has been established as the aetiological agent of these lesions, as shown by detecting viral particles on electron microscopy, ${ }^{3}$ HPV structural proteins by immunohistochemistry, ${ }^{45}$ and HPV DNA by DNA hybridisation methods. ${ }^{6-9}$ 
Strong evidence has accumulated during the past 10 years suggesting that certain HPV infections of the female genital tract are also intimately linked with the development of premalignant and malignant squamous cell lesions. Above all, intraepithelial neoplasia (IN) has been associated with the so-called high risk HPV types, HPV 16, 18, 31, and 33.471016-19 Similarly, epithelial atypia has been reported in penile lesions, in particular those classified as bowenoid papulosis, which invariably seem to yield high risk HPV types. ${ }^{720-23}$ Several reports of malignant transformation of anal warts also exist, ${ }^{1024-29}$ and some cases of anal warts have been associated with multiple squamous cell neoplasia in the genitoanal region. ${ }^{30}$ HPV DNA has been detected in several anal squamous cell carcinomas. ${ }^{31} 32$

Anal condylomas currently represent an increasingly severe clinical problem, especially in homosexual men, immunosuppressed patients, and possibly also sexually abused children. ${ }^{5710-15}$ Because of the tendency to develop malignancies that has recently been ascribed to certain HPV types, their detection by DNA hybridisation techniques has become an essential tool in assessing the potential malignancy of condylomas, including those of the anus. ${ }^{161719}$ In this respect, the high risk HPV types, 16 and 18, are of special interest as they possess the potential to integrate in the host cell genome. $^{33} 34$

We carried out the present study of a representative series of anal condylomas collected from heterosexual and homosexual or bisexual men to assess the prevalence of the low risk (HPV 6 and 11) and high risk (HPV 16, 18, 31 and 33) HPV types, using the in situ DNA hybridisation assay. These HPV types were correlated with condylomas showing various gross appearances and with anal intraepithelial neoplasia (AIN). Furthermore, we analysed the potential relation between these variables and the sexual preference and HIV-antibody status of patients and the duration and number of previous treatments given for their warts.

\section{Patients, materials, and methods}

\section{PATIENTS}

We studied 111 men (73 homosexual or bisexual, 38 heterosexual) encountered during a 19 month period in 1986-7 at the outpatient department of dermatology, Södersjukhuset, Stockholm, Sweden. Patients were selected arbitrarily from consecutive men attending the division for sexually transmitted diseases (STD) with anal warts that were previously untreated or recalcitrant, which were operated on after the patient had given informed consent. These patients were partly encountered in a general STD setting, and partly in a specialised STD clinic for homosexual and bisexual men. The mean (SD) age of the patients was $31.8(9.6)$ years, $63 \%$ of the men being aged $20-35$.

The patients were subjected to careful clinical examination by the same physician (GvK), and the duration of the lesions and number of treatments before admission to hospital were recorded. The exact locations of the warts were recorded as being either intra-anal, anal, perianal, or genital. ${ }^{35}$ On gross morphology, the lesions were classified as being in one of the following categories: predominantly exophytic acuminate warts, rounded papular warts, flat lesions presenting as only a slight elevation of the epidermal contour, and lesions suspected of showing bowenoid papulosis (having prominent pigmentation or a brownish-red colour). The clinical part of this study will be accounted for separately in a subsequent report.

One or more biopsy specimens were collected from the anogenital area of each patient. A sample was also collected from any recurrent penile lesion. A total of 136 condylomas were biopsied from the 111 patients examined. Biopsy samples were immediately frozen and stored at $-70^{\circ} \mathrm{C}$ until being further processed.

\section{MORPHOLOGICAL ASSESSMENT}

The frozen biopsy specimens were thawed, fixed in $10 \%$ neutral formalin, and processed for routine light microscopy. In sections stained with haematoxylin and eosin the light microscopic appearance of the lesions was analysed using the criteria outlined previously for condyloma acuminatum, flat condyloma, pigmented papulosis, and bowenoid papulosis. ${ }^{12236}$ Grades of intraepithelial neoplasia were recorded using the commonly accepted criteria for AIN I, AIN II, and AIN III. ${ }^{472}$ Lesions not showing concomitant AIN were described as showing NAIN (non-anal intraepithelial neoplasia).

\section{HPV TYPING}

For HPV typing, DNA probes of HPV types 6, 11, 16, 18,31 , and 33 were used to perform the in situ DNA hybridisation technique on paraffin sections. The technique currently used in our laboratory ${ }^{37}$ is a slight modification of that described previously in detail ${ }^{38} 39$ The specimens were hybridised for 50 hours at $42^{\circ} \mathrm{C}$ in a humidified chamber under conditions of high stringency ( $\mathrm{Tm}$ (melting temperature) $-17^{\circ} \mathrm{C}$ ). After hybridisation, the sections were placed in lightproof boxes for four days. The black autoradiography grains superimposed on the nuclei of epithelial cells (figs 1-3) indicated HPV DNA sequences in the lesions, as described previously. ${ }^{37-39}$

\section{Results}

Table 1 shows the incidence of any AIN in 128 anal lesions characterised by light microscopy. Acuminate 


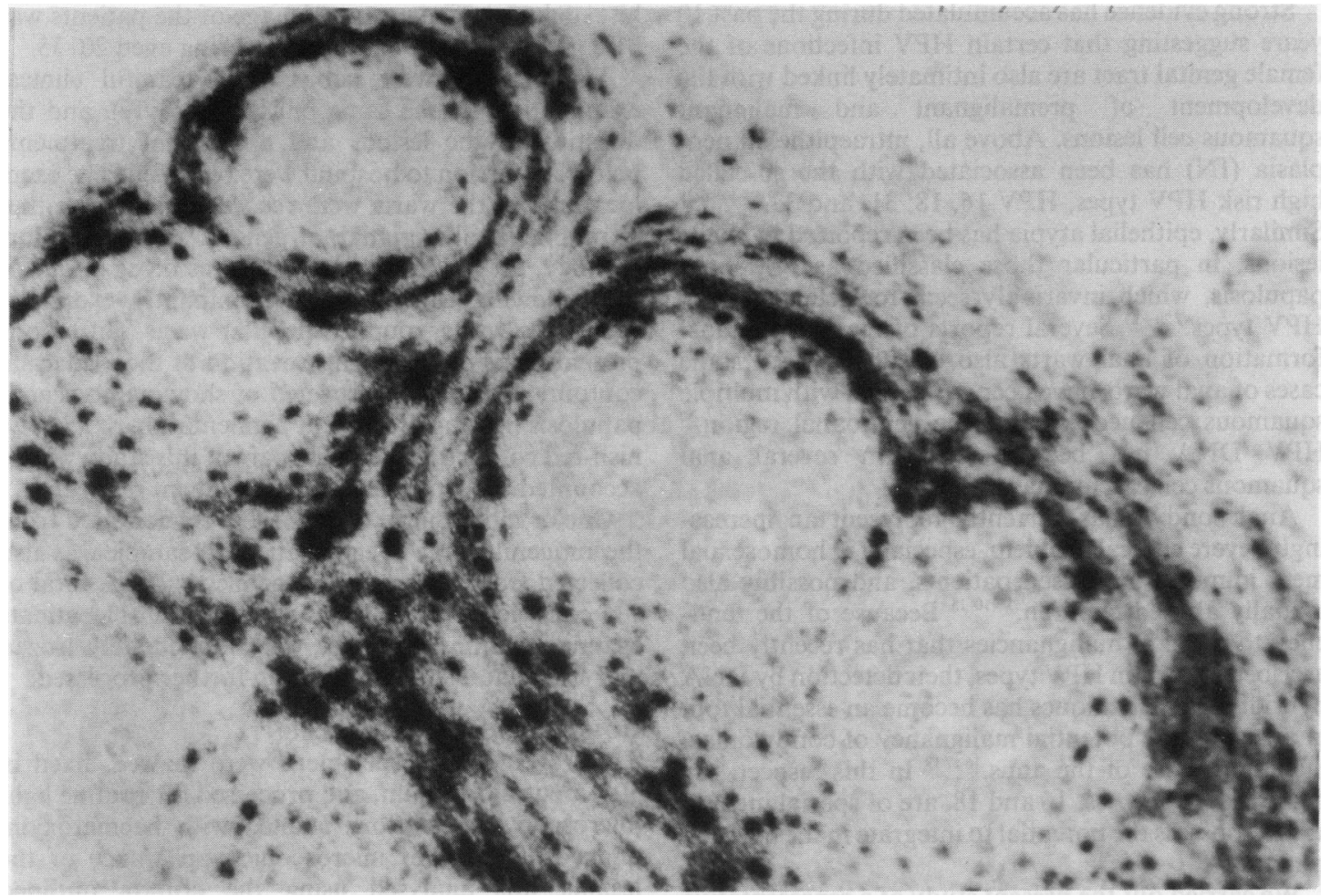

Fig 1 Anal condyloma acuminatum subjected to in situ hybridisation with HPV 11 DNA probe under stringent conditions. (Black silver grains (after autoradiography), which indicate HPV 11 DNA, superimposed on nuclei of many koilocytotic cells in intermediate and superficial layers). (In situ DNA hybridisation for HPV 11, haematoxylin and eosin counterstain.)

and flat warts showed little difference regarding their associated AIN, as shown by the similar incidence of NAIN, AIN I, and AIN II in these two types of lesions. On the other hand, AIN was significantly $(p<0.05)$ associated with papulous lesions, only $43 \%$ of which were NAIN compared with $72 \%$ of the exophytic condylomas.

Table 2 relates the durations of 125 lesions to the histological grade of AIN. The observations showed a trend indicating that the duration of disease was directly related to the presence and severity of AIN. In the 47 lesions that had been present for more than 12

Table 1 Morphology on light microscopy of 128 anal human papillomavirus (HPV) lesions related to degree of anal intraepithelial neoplasia ( $A I N$ ) (figures are numbers (percentages) of lesions of given morphology)

\begin{tabular}{lcrrr}
\hline Morphology & Total & \multicolumn{1}{c}{ NAIN } & \multicolumn{1}{c}{ AIN I } & \multicolumn{1}{c}{ AIN II } \\
\hline Acuminate & $95(74)$ & $68(72)$ & $26(27)$ & \multicolumn{1}{c}{$1(1)$} \\
Flat & $19(15)$ & $16(84)$ & $3(16)$ & \multicolumn{1}{c}{0} \\
Papulous & $14(11)$ & $6(43)$ & $6(43)$ & $2(14)$ \\
Total & 128 & $90(70)$ & $35(27)$ & $3(2)$ \\
\hline
\end{tabular}

NAIN = No anal intraepithelial neoplasia. months, NAIN was found in $66 \%$, AIN I in $30 \%$, and AIN II in 4\%.

The 125 anal lesions were tested further with the in situ hybridisation assay and $109(87 \%)$ gave positive signals for one of the six test probes. Table 3 shows the distribution of HPV types $6,11,16,18,31$, and 33 in the 109 lesions according to their gross morphology (as evaluated by the clinician before biopsy). HPV 6 and 11 , which accounted for $57 \%(62 / 109)$ and $37 \%$ $(40 / 109)$ respectively, and represented the predominant viral types, were both found most in acuminate

Table 2 Duration of 125 human papillomavirus (HPV) lesions related to degree of anal intraepithelial neoplasia (AIN) (figures are numbers (percentages) of lesions of given duration)

\begin{tabular}{lcrrl}
\hline $\begin{array}{l}\text { Duration } \\
\text { (months) }\end{array}$ & Total & NAIN & AIN I & AIN II \\
\hline $0-1$ & $11(9)$ & $8(73)$ & $3(27)$ & 0 \\
$2-5$ & $35(28)$ & $25(71)$ & $9(26)$ & $1(3)$ \\
$6-12$ & $32(26)$ & $24(75)$ & $8(25)$ & 0 \\
over 12 & $47(38)$ & $31(66)$ & $14(30)$ & $2(4)$ \\
Total & 125 & $88(70)$ & $34(27)$ & $3(2)$ \\
\hline
\end{tabular}




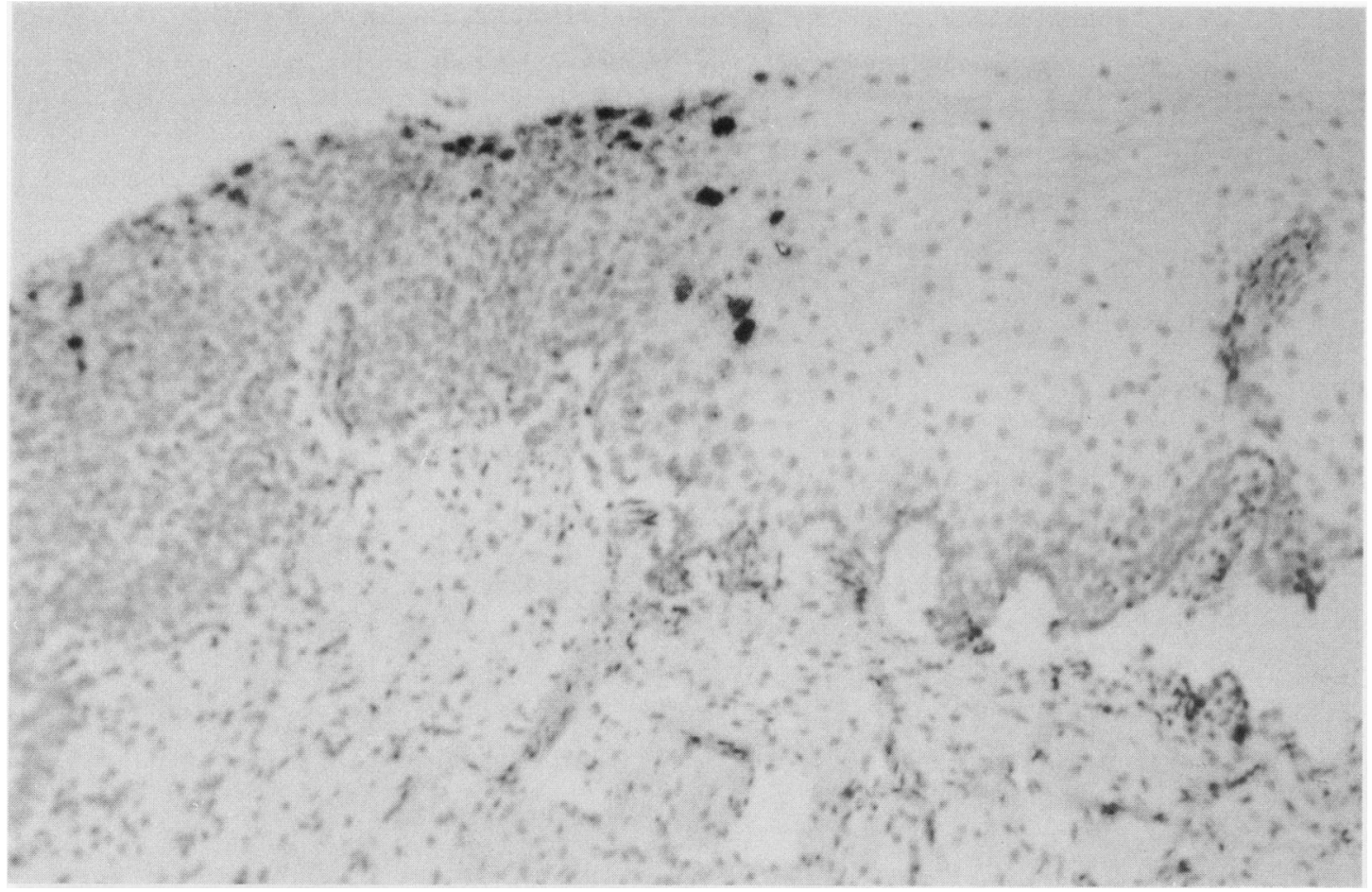

Fig 2 Anal flat condyloma associated with AIN II. Biopsy specimen processed under stringent conditions by in situ DNA hybridisation with HPV 16 DNA probe. (Intense signals superimposed on nuclei of some superficial cells, which indicates HPV 16 DNA in relatively high copy numbers in these cells. Note the abrupt change from AIN (on the left) to normal epithelium (on the right) paralleled by the disappearance of HPV DNA.) (In situ DNA hybridisation for HPV 16, haematoxylin and eosin counterstain.)

warts. High risk HPV types, 16, 18, 31, and 33, were detected in only seven $(6 \%)$ lesions, five acuminate, one papulous, and one flat. A clinical suspicion of bowenoid lesions appeared to have no predictive value for detecting high risk HPV types; all four such lesions yielded HPV 6 or 11 only.

Altogether 109 anal and three penile lesions gave positive results in the in situ hybridisation assay. These 112 lesions are listed in table 4 with reference to HPV types detected when correlated with morphological appearance on light microscopy. As when evaluated clinically, the acuminate type of warts predominated.
Some discrepancy existed between gross and light microscopic appreciation of the morphology; $70 \%$ (76/109) were classified clinically as being of the acuminate type, whereas the corresponding figure for microscopic assessment was $81 \%$ (91/112). Again, however, HPV 6 and 11 were most commonly associated with acuminate warts, although these HPV types were also the most common ones in papulous and flat lesions. As with the findings by gross appreciation, high risk HPV types were most commonly encountered in acuminate lesions, although both lesions harbouring HPV 16 were of the flat type.

Table 3 Gross appearance of 109 anal warts related to human papillomavirus (HPV) type detected by in situ hybridisation (figures are numbers (percentages) of lesions with given HPV type)

\begin{tabular}{lccccccc}
\hline $\begin{array}{l}\text { Gross } \\
\text { appearance }\end{array}$ & Total & HPV 6 & HPV II & HPV 16 & HPV I8 & HPV 3I & HPV 33 \\
\hline Acuminate & 76 & $38(61)$ & $33(83)$ & $1(50)$ & $1(100)$ & $1(50)$ & $2(100)$ \\
Papulous & 22 & $16(26)$ & $5(13)$ & 0 & 0 & $1(50)$ & 0 \\
Flat & 7 & $5(8)$ & $1(3)$ & $1(50)$ & 0 & 0 & 0 \\
Bowenoid & 4 & $3(5)$ & $1(3)$ & 0 & 0 & 0 & 0 \\
Total & 109 & $62(100)$ & $40(100)$ & $2(100)$ & $1(100)$ & $2(100)$ & $2(100)$ \\
\hline
\end{tabular}




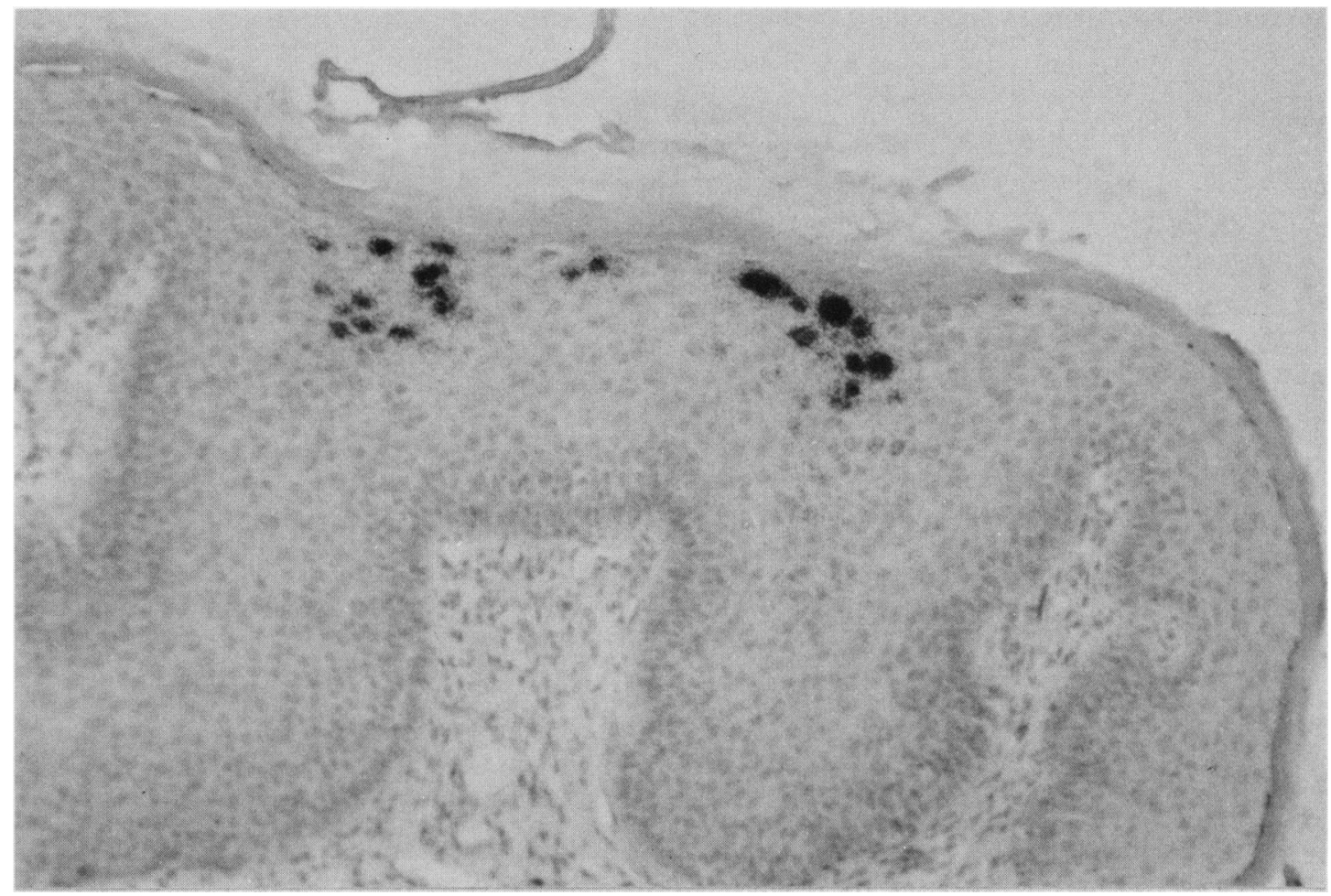

Fig 3 Raised papular and HPV lesion characterised by acanthotic squamous epithelium with abundant koilocytes (the cytopathic effect of HPV) subjected to in situ hybridisation with HPV 6 DNA probe. (Most koilocytotic cells have dense condensations of silver grains on their nuclei, which indicates HPV 6 DNA in very high copy numbers (many hundreds/cell). (In situ DNA hybridisation for HPV 6, haematoxylin and eosin counterstain.)

Table 5 shows the distribution of HPV types in anal and penile lesions of various grades of AIN. Atypia were absent (NAIN) in $69 \%(77 / 112)$ of the samples. NAIN did not correlate with any particular HPV type, but was found in $73 \%(47 / 64)$ of lesions harbouring HPV type 6 and $63 \%(26 / 41)$ of those with type 11, as well as in $57 \%(4 / 7)$ of those carrying high risk HPV types. The two lesions containing HPV 16 as well as one of the two HPV 33 associated lesions were graded AIN I. It is noteworthy that both lesions graded AIN II contained HPV 6.

Table 6 shows that there was no association between sexual preferences of the patients and the incidence of any HPV type. The same was true regarding antibody to HIV and the incidence of HPV types (table 7). Both the HPV 16 associated lesions were found in patients without antibody to HIV.

Table 8 depicts the duration of disease related to the different HPV types. No differences were found between HPV 6 and HPV 11 regarding duration of disease; lesions that had been present for more than 12 months accounted for $39 \%$ (24/62) of HPV 6 and $37 \%$ $(15 / 41)$ of HPV 11 lesions. HPV 16, 18, and 33 tended to be associated with lesions of more prolonged

Table 4 Microscopic appearance related to human papillomavirus (HPV) type discovered by in situ hybridisation of 109 anal and three penile warts (figures are numbers (percentages) of lesions with given HPV type)

\begin{tabular}{|c|c|c|c|c|c|c|c|}
\hline $\begin{array}{l}\text { Microscopic } \\
\text { appearance }\end{array}$ & Total & $H P V 6$ & $H P V 11$ & HPV 16 & HPV 18 & $H P V 31$ & $H P V 33$ \\
\hline $\begin{array}{l}\text { Acuminate } \\
\text { Flat } \\
\text { Papulous }\end{array}$ & $\begin{array}{l}91 \\
11 \\
10\end{array}$ & $\begin{array}{rr}48 & (75) \\
8 & (13) \\
8 & (13)\end{array}$ & $\begin{array}{rr}38 & (93) \\
1 & (2) \\
2 & (5)\end{array}$ & $\begin{array}{l}0 \\
2(100) \\
0\end{array}$ & $\begin{array}{l}1(100) \\
0 \\
0\end{array}$ & $\begin{array}{l}2(100) \\
0 \\
0\end{array}$ & $\begin{array}{l}2(100) \\
0 \\
0\end{array}$ \\
\hline Total & 112 & $64(100)$ & $41(100)$ & $2(100)$ & $1(100)$ & $2(100)$ & $2(100)$ \\
\hline
\end{tabular}


Table 5 Degree of anal intraepithelial neoplasia (AIN) correlated with human papillomavirus (HPV) type discovered by in situ hybridisation (figures are numbers (percentages) of lesions with given HPV type)

\begin{tabular}{lrllllll}
\hline $\begin{array}{l}\text { Grade of } \\
\text { AIN }\end{array}$ & No & $H P V 6$ & $H P V I 1$ & $H P V 16$ & $H P V 18$ & $H P V 31$ & $H P V 33$ \\
\hline NAIN & 77 & $47(73)$ & $26(63)$ & 0 & $1(100)$ & $2(100)$ & $1(50)$ \\
AIN I & 33 & $15(23)$ & $15(37)$ & $2(100)$ & 0 & 0 & 1 \\
AIN II & 2 & $2(3)$ & 0 & 0 & 0 & 0 & 0 \\
Total & 112 & $64(100)$ & $41(100)$ & $2(100)$ & $1(100)$ & $2(100)$ & $2(100)$ \\
\hline
\end{tabular}

Table 6 Sexual preference correlated with human papillomavirus (HPV) DNA type discovered by in situ hybridisation of 109 lesions (figures are numbers (percentages) of lesions with given HPV type)

\begin{tabular}{lcllllll}
\hline $\begin{array}{l}\text { Sexual } \\
\text { preference }\end{array}$ & No & HPV 6 & HPV II & HPV 16 & HPV 18 & HPV 31 & HPV 33 \\
\hline Heterosexual & 43 & $23(37)$ & $17(43)$ & $2(100)$ & 0 & 0 & $1(50)$ \\
Homosexual or bisexual & 66 & $39(63)$ & $23(58)$ & 0 & $1(100)$ & $2(100)$ & $1(50)$ \\
Total & 109 & $62(100)$ & $40(100)$ & $2(100)$ & $1(100)$ & $2(100)$ & $2(100)$ \\
\hline
\end{tabular}

duration, but no significant differences were found between the number of previous treatments and the various HPV types (data not shown).

\section{Discussion}

According to reports published previously, anal warts are several times more common than penile warts in homosexual men. ${ }^{112}$ In a recent survey of 682 homosexual men, $22.3 \%$ had anal warts at the time or in the past." A possible explanation of this discrepancy might be that the moist and warm perirectal area is more conducive to the growth of warts than the somewhat drier and cooler squamous epithelium of the penis. " An alternative explanation could be that, in analogy to the conditions of the uterine cervix, a transitional zone (TZ) exists in the anal canal between the squamous and columnar epithelium. ${ }^{35}$ The TZ of the cervix seems to represent a locus minoris for infection with HPV by vaginal intercourse. ${ }^{16-18}$ Similarly, anal receptive intercourse may predispose to introducing the virus into the anorectral $\mathrm{TZ}$, which seems particularly sensitive to mechanical trauma. This may permit the access of viral particles into the basal cells, which are the suggested target of HPV infection..$^{16-18}$ In addition, receptive anal intercourse may predispose to reduced local cell mediated immune defence by impairing the function of the Langerhans cells.

The exceptionally high incidence of anal warts in homosexual men confirms the need for continued research, ${ }^{11}{ }^{12}$ particularly because of recent reports of high incidences of precancerous lesions and anal squamous cell carcinomas in these men. ${ }^{51027}$ More recently, the malignant transformation of these lesions has been linked with impaired immunity caused by infection with HIV. ${ }^{10}$ The increased recognition of HPV as an important agent in the pathogenesis of genital cancer has also led this infection to be associated with the development of anal squamous cell cancer. $^{58102432}$ This concept is strongly supported by the recent discovery of the high risk HPV type 16 DNA in anal carcinomas. ${ }^{31}{ }^{3241}$ This HPV type is also the one most often associated with a recently described entity called bowenoid papulosis, ${ }^{720-22}$ which is found in the external genitalia and in the perianal region. ${ }^{22}{ }^{40} \mathrm{HPV}$ types 6 and 11 (low risk), however, have also been discovered in a squamous cell carcinoma arising in a perianal giant condyloma. ${ }^{9}$

Because of the lack of systematic surveys of HPV types associated with anal condylomas, the present study was conducted to assess a representative series of anal warts collected from heterosexual and homosexual or bisexual men for the incidence of the low risk (HPV 6 and 11) and high risk (HPV 16, 18, 31, and 33) HPV types by in situ DNA hybridisation, related to some relevant clinical and histopathological variables. We found it of special interest to elucidate to what extent anal HPV lesions exhibiting varying gross appearances were associated with anal intraepithelial neoplasia (AIN), ${ }^{24}$ and whether these data were related to the sexual preferences of the patients, their HIV antibody status, the duration of the disease, or the number of previous treatments.

Surprisingly, anal acuminate and flat condylomas did not appear to differ greatly regarding their associated AIN, as shown by similar incidences of NAIN, AIN I, and AIN II in these lesions (table 1). Indeed, AIN I was found in $27 \%$ of typical condylomata acuminata and $16 \%$ of flat warts. That did not accord with data on cervical ${ }^{16}{ }^{17}$ or penile HPV infection, ${ }^{19}$ in which flat lesions were significantly more 
Table 7 Results of serological tests for antibody to human immunodeficiency virus (HIV) related to human papillomavirus (HPV) DNA type discovered by in situ hybridisation of 112 lesions (figures are numbers (percentages) of lesions with given HPV type)

\begin{tabular}{lcccllll}
\hline $\begin{array}{l}\text { HIV } \\
\text { antibody }\end{array}$ & No & HPV 6 & HPV II & HPV 16 & HPV 18 & HPV 3I & HPV 33 \\
\hline Negative & 81 & $46(72)$ & $30(73)$ & $2(100)$ & $1(100)$ & $1(50)$ & $1(50)$ \\
Positive & 21 & $12(19)$ & $7(17)$ & 0 & 0 & $1(50)$ & $1(50)$ \\
No data & 10 & $6(9)$ & $4(10)$ & 0 & 0 & 0 & 0 \\
Total & 112 & $64(100)$ & $41(100)$ & $2(100)$ & $1(100)$ & $2(100)$ & $2(100)$ \\
\hline
\end{tabular}

Table 8 Duration of disease related to human papillomavirus (HPV) DNA type discovered by in situ hybridisation of 109 lesions (figures are numbers (percentages) of lesions with given HPV type)

\begin{tabular}{|c|c|c|c|c|c|c|c|}
\hline $\begin{array}{l}\text { Duration } \\
\text { (months) }\end{array}$ & No & HPV 6 & $H P V 11$ & HPV 16 & HPV 18 & $H P V 31$ & HPV 33 \\
\hline $\begin{array}{l}0-1 \\
2-5 \\
6-12 \\
\text { over } 12\end{array}$ & $\begin{array}{r}6 \\
29 \\
32 \\
42\end{array}$ & $\begin{array}{rr}3 & (5) \\
14 & (23) \\
21 & (34) \\
24 & (39)\end{array}$ & $\begin{array}{rr}3 & (7) \\
13 & (32) \\
9 & (22) \\
15 & (37)\end{array}$ & $\begin{array}{ll}0 & \\
0 & \\
1 & (50) \\
1 & (50)\end{array}$ & $\begin{array}{l}0 \\
0 \\
0 \\
1(100)\end{array}$ & $\begin{array}{ll}0 & \\
1 & (50) \\
1 & (50) \\
0 & \end{array}$ & $\begin{array}{ll}0 & \\
1 & (50) \\
0 & \\
1 & (50)\end{array}$ \\
\hline Total & 109 & $62(100)$ & $41(100)$ & $2(100)$ & $1(100)$ & $2(100)$ & $2(100)$ \\
\hline
\end{tabular}

often associated with intraepithelial neoplasia than were condylomata acuminata. This emphasises the importance of taking adequate biopsy specimens from all condylomas, and examining them by light microscopy for concomitant AIN. In the present series, AIN was significantly most commonly associated with papulous lesions, being found in $57 \%(8 / 14)$ of them. Thus, as found in the external genitalia, ${ }^{36}$ papulosis type HPV lesions in the anal region were also found more often than other types concomitantly with intraepithelial neoplasia.

The clinical data concerning the duration of disease and its treatment will be discussed in more detail elsewhere. A trend indicated that the duration of disease was directly correlated with the severity of the lesions (table 2). This was most pronounced in the 47 lesions that had been present for more than 12 months, of which showed only $66 \%$ showed AIN I, $30 \%$, and $4 \%$ AIN II.

HPV DNA of at least one of the above six types was found in as many as 109 of the 125 anal lesions (87\%). This high incidence of HPV positivity obtained by in situ DNA hybridisation was consonant with our previous experience with penile warts, ${ }^{19}$ but the figures are higher than those reported for genital tract lesions in women. ${ }^{16}{ }^{17}$ HPV 6 and HPV 11 were the two most common types, comprising $62(59 \%)$ and $40(37 \%)$ respectively, of the 109 HPV DNA positive warts. As much as $83 \%$ of HPV 11 positive and $61 \%$ of HPV 6 positive lesions proved to be condylomata acuminata. The incidence of HPV 6 was fairly high $(26 \%)$ in papulous lesions. The high risk HPV types, 16, 18, 31, and 33 , were detected in only seven $(6 \%)$ of the biopsy specimens; they occurred equally in acuminate, papulous, and flat lesions. Surprisingly, neither of the clinically conspicious bowenoid lesions contained any high risk HPV types. Thus evaluating gross appearances of warts was of no value for predicting infection with high risk HPV types.

The incidence of HPV types in the three histopathologically differentiated types of lesions closely paralleled that in lesions differentiated by their gross appearance. A total of $93 \%$ (38/41) of HPV 11 lesions were condylomata acuminata. The corresponding figure for HPV 6 was $75 \%$ (48/64). HPV 6 DNA was found equally commonly in the flat and papulosis lesions (each type accounted for $13 \%$ of the HPV 6 lesions), whereas only $7 \%(3 / 41)$ of lesions containing HPV 11 were flat or papulous. Both of the HPV 16 associated lesions were of the flat type, whereas the other high risk types, HPV 18, 31, and 33, were confined to acuminate warts. These figures differed to some extent from those we reported for penile condylomas, ${ }^{19}$ which showed that HPV 16 or 18 occurred most in bowenoid lesions, though more than half the penile lesions containing these HPV types were flat or acuminate.

On relating the various HPV types to the grades of intraepithelial neoplasia (table 5) our findings for anal condylomas confirmed our previous findings for penile lesions. Of the HPV 6 associated lesions in the present study, $73 \%$ were classified as NAIN; this figure was $63 \%$ for the HPV 11 associated lesions. The corresponding figures for HPV 6 and HPV 11 in our previous study of penile warts were $56 \%$ and $42 \%$, respectively. ${ }^{19}$ Both of the HPV 16 associated lesions in the present series showed AIN I, which was similar to our findings in penile lesions, in which $60 \%(6 / 10)$ 
HPV 16 or 18 induced lesions showed no, or only mild, dysplasia. The discovery of HPV 6 DNA in two patients with AIN II in the present series was remarkable and confirmed previous results, including those found in women, which indicated that HPV type cannot be predicted from the light microscopic appearance of lesions alone unless severe dysplasia is found, when the presence of high risk HPV types is very likely. 161719

The distribution of the six HPV types in homosexual or bisexual men was identical to that in heterosexual men, and no particular HPV type preponderated according to the sexual preferences of the patients (table 6). High risk HPV types were no more common in men with antibody to HIV than in those who were HIV negative (table 7). The even distribution of the various HPV types in HIV positive and negative patients indicated that the immunosuppression associated with HIV infection did not in itself predispose men to anal lesions induced by any specific HPV types.

In conclusion, the results of the study published here indicated that papular and longlasting anal condylomas tended to be associated most with more severe AIN. The underlying HPV type cannot be predicted reliably on the basis of any of the following variables: the gross appearance of lesions, their anatomical location, the sexual preferences of patients, their HIV antibody status, or appraisal, including that of any concurrent AIN, on light microscopy. Adequate assessment of each patient with anal condylomata that have been present for more than a year should include taking a careful clinical history and undertaking a directed biopsy of warts to evaluate any AIN. The use of in situ DNA hybridisation is advocated for further scientific studies; this method has the advantage that it can be applied to sections fixed in formalin and embedded in paraffin, which are used for routine histology. This method also excludes any potential health hazards to laboratory staff from HIV infections, which are often found in patients with anal warts.

This investigation was supported by PHS grant number 5 R01 CA 42010-02 awarded by the National Cancer Institute, DHHS, a research grant from the Finnish Cancer Society, and a research grant from the Social Insurance Institution of Finland

We thank Mrs Heli Eskelinen, Mrs Pirkko Karttunen, Miss Helena Kemiläinen, Mrs Sari Pennanen, Miss Ritva Savolainen, and Miss Eija Varis for their technical help, and Professor Harald zur Hausen, Deutsches Krebsforschungszentrum, Heidelberg, West Germany, and Professor Gerard Orth, Pasteur Institute, Paris, France, for providing the HPV DNA probes.

\section{References}

1 Oriel JD. Genital warts. Sex Transm Dis 1981;8:326-9.
2 Moore GE, Norton LW, Meiselbaugh DM. Condyloma. A new epidemic. Arch Surg 1978;113:630-1.

3 Hills E, Laverty CR. Electron microscopic detection of papillomavirus particles in selected koilocytotic cells in routine cervical smears. Acta Cytol 1979;23:53-6.

4 Lancaster WD, Kurman RJ, Jenson AB. Papillomaviruses in anogenital neoplasms. In: Luderer $\mathrm{AA}$, Weetall $\mathrm{HH}$, eds. The human oncogenic viruses. Clifton, New Jersey, USA: Humana Press, 1986:153-83.

5 Gal AA, Meyer PR, Taylor CR. Papillomavirus antigens in anorectal condyloma and carcinoma in homosexual men. JAMA 1987;257:337-40.

6 Gissmann L, Boshart M, Dürst M, Ikenberg H, Wagner D, zur Hausen H. Presence of human papillomavirus in genital tumors. J Invest Dermatol 1984;83:26s-28s.

7 Gross G, Gissmann L. Urogenitale und anale Papillomavirusinfektionen. Hautarzt 1986;37:587-96.

8 Henderson BR, Thompson CH, Rose BR, Cossart YE, Morris BJ. Detection of specific types of human papillomavirus in cervical scrapes, anal scrapes, and anogenital biopsies by DNA hybridization. J Med Virol 1987;21:381-93.

9 Wells M, Robertson S, Lewis F, Dixon MF. Squamous carcinoma arising in a giant peri-anal condyloma associated with human papillomavirus types 6 and 11. Histopathology 1988;12:319-23.

10 Croxson T, Chabon AB, Rorat E, Barash IM. Intraepithelial carcinoma of the anus in homosexual men. Dis Colon Rectum 1984;27:325-30.

11 Carr G, William B, William DC. Anal warts in a population of gay men in New York city. Sex Transm Dis 1977;4:56-7.

12 Oriel JD. Anal warts and anal coitus. British Journal of Venereal Diseases 1971;47:373-6.

13 Vallejos H, Del Mistro A, Kleinhaus S, Braunstein JD, Halwer M, Koss LG. Characterization of human papilloma virus types in condylomata acuminata in children by in situ hybridization. Lab Invest 1987;56:611-5.

14 Penn I. Cancers of the anogenital region in renal transplant recipients. Cancer 1986;58:611-6.

15 Fleming KA, Venning V, Evans M. DNA typing of genital warts and diagnosis of sexual abuse of children. Lancet 1987;ii:454.

16 Syrjänen KJ. Human papillomavirus (HPV) lesions in association with cervical dysplasias and neoplasias. Obstet Gynecol 1983; 62:617-24.

17 Syrjänen KJ. Biology of human papillomavirus (HPV) infections and their role in squamous cell carcinogenesis. Med Biol 1987; 65:21-39.

18 Broker TR, Botchan M. Papillomaviruses: retrospectives and prospectives. DNA tumor viruses. Cancer Cells 1986;4:17-36.

19 Syrjänen SM, von Krogh G, Syrjänen KJ. Detection of human papillomavirus DNA in anogenital condylomata in men using in situ DNA hybridisation applied to paraffin sections. Genitourin Med 1987;63:32-9.

20 Patterson JW, Kao GF, Graham JH, Helwig EB. Bowenoid papulosis. Cancer 1986;57:823-36.

21 Gross G, Hagedorn M, Ikenberg H, Rufli T, Dahlet C, Grosshans E, Gissmann L. Bowenoid papulosis. Arch Dermatol 1985; 121:858-63.

22 Gross G, Hagedorn M, Ikenberg H, Rufli T, Dahlet C, Grosshans E, Gissmann L. Bowenoid papulosis. Presence of human papillomavirus (HPV) structural antigens and of HPV 16related DNA sequences. Arch Dermatol 1985;121:858-63.

23 Ikenberg H, Gissmann L, Gross G, Grussendorf-Conen E-I, zur Hausen H. Human papillomavirus type 16-related DNA in genital Bowen's disease and in Bowenoid papulosis. Int J Cancer 1983;32:563-5.

24 Fenger $C$, Nielsen VT. Intraepithelial neoplasia in the anal canal. Acta Pathol Microbiol Immunol [A] 1986;94:343-9.

25 Prasad ML, Abcarian H. Malignant potential of perianal condyloma acuminatum. Dis Colon Rectum 1980;23:191-7.

26 Lee SH, McGregor DH, Kuziez MN. Malignant transformation of perianal condyloma acuminatum. Dis Colon Rectum 1981; 24:462-7. 
27 Oriel JD, Whimster W. Carcinoma in situ associated with viruscontaining anal warts. Br J Dermatol 1971;84:71-3.

28 Bogomoletz WV, Potet F, Molas G. Condylomata acuminata, giant condyloma acuminatum (Buschke-Loewenstein tumour) and anorectal region: a continuous precancerous spectrum? Histopathology 1985;9:1155-69.

29 Ejeckam GC, Idikio HA, Nayak V, Gardiner JP. Malignant transformation in an anal condyloma acuminatum. Can J Surg 1983;26:170-3.

30 Choo Y-C, Morley GW. Multiple primary neoplasms of the anogenital region. Obstet Gynecol 1980;56:365-8.

31 Palmer JG, Shepherd NA, Jass JR, Crawford LV, Northover JMA. Human papillomavirus type 16 DNA in anal squamous cell carcinoma. Lancet 1987; i:42.

32 Hill SA, Coghill SB. Human papillomavirus in squamous carcinoma of anus. Lancet 1986;ii:1333.

33 Dürst M, Gissmann L, Ikenberg H, zur Hausen H. A papíllomavirus DNA from a cervical carcinoma and its prevalence in cancer biopsy samples from different geographic regions. Proc Natl Acad Sci USA 1983;80:3812-5.

34 Boshart M, Gissmann L, Ikenberg H, Kleinheinz A, Scheurlen W, zur Hausen $H$. A new type of papillomavirus DNA, its presence in genital cancer biopsies and in cell lines derived from cervical cancer. EMBO J 1984;3:1151-7.

35 Fenger C. Histology of the anal canal. Am J Surg Pathol 1988;
12:41-55.

36 Gross G, Ikenberg H, Gissmann L, Hagedorn M. Papillomavirus infection of the anogenital region: correlation between histology, clinical picture, and virus type. Proposal of a new nomenclature. J Invest Dermatol 1985;85:147-52.

37 Syrjänen S, Partanen P, Mäntyjärvi R, Syrjänen K. Sensitivity of in situ hybridization techniques using biotin- and ${ }^{35} \mathrm{~S}$-labelled human papillomavirus (HPV) DNA probes. $J$ Virol Methods 1988;19:225-38.

38 Syrjänen S, Syrjänen K, Mäntyjärvi R, et al. Human papillomavirus (HPV) DNA sequences demonstrated by in situ DNA hybridization in serial paraffin-embedded cervical biopsies. Arch Gynecol 1986;239:39-48.

39 Syrjänen S, Syrjänen K. An improved in situ DNA hybridization protocol for detection of human papillomavirus (HPV) DNA sequences in paraffin-embedded sections. J Virol Methods 1986; 14:293-304.

40 Fiumara NJ, Wagner RF. Perianal Bowen's disease associated with anorectal warts: a case report. Sex Transm Dis 1987;14: 58-60.

41 Wells M, Griffiths S, Lewis F, Bird CC. Demonstration of human papillomavirus types in paraffin processed tissue from human anogenital lesions by in situ DNA hybridization. $J$ Pathol 1987;152:77-82. 